\title{
The Influence of High Sugar Intake on Cognitive Functions and Body Composition of University Students
}

\author{
Joany Lizet Hernández ${ }^{1}$ - Jiří Čeněk² - Martin Čuta ${ }^{3}$ \\ 1 Department of Languages and Cultural Studies, Faculty of Regional Development and International Studies, \\ Mendel University in Brno, tř. Generála Píky 7, 61300 Brno, Czech Republic \\ 2 Department of Social Development, Faculty of Regional Development and International Studies, Mendel University in Brno, \\ tř. Generála Píky 7, 61300 Brno, Czech Republic Pilsen \\ 3 Department of Anthropology, Faculty of Science, Masaryk University, Kotlářská 2, 61137 Brno, Czech Republic
}

Received $24^{\text {th }}$ November 2016; accepted $2^{\text {th }}$ June 2017

\section{VLIV NADMĚRNÉHO PŘÍSUNU CUKRU NA KOGNITIVNÍ SCHOPNOSTI A TĚLESNÉ SLOŽENÍ UNIVERZITNÍCH STUDENTŮ}

ABSTRAKT Volné cukry se podílejí na výživové hodnotě stravy a přispívají k vyváženému př́imu energie. Dle údajů WHO je doporučený př́jem cukrů u dospělého člověka s normálním BMI $25 \mathrm{~g} / \mathrm{den}$. Euromonitor International ale uvádí, že množství cukrů konzumovaných v České republice dosahuje $71,6 \mathrm{~g} / \mathrm{den}$. Nadměrný př́jem cukru může zvýšit výskyt civilizačních chorob a může mít vliv na kognitivní schopnosti. Cílem této studie bylo stanovit dopady vysokého př́ijmu cukru na hmotnost, tělesné složení (s využitím metody BIA - př́stroj Bodystat $1500 \mathrm{MDD})$ a schopnost učit se u vysokoškolských studentů $(\mathrm{N}=107)$ rozdělených do dvou skupin. Zatímco členové experimentální skupiny byli instruováni, aby dodržovali dietu bez cukru, u kontrolní skupiny žádná konkrétní dieta stanovena nebyla. Pomocí testu LGT-3 a bioimpendance pak byly měřeny různé proměnné. Měření probíhalo jak na začátku experimentu, tak po uplynutí jednoho měsíce (experiment dokončilo 33 účastníků). Mezi experimentální a kontrolní skupinou nebyly po ukončení experimentu zjištěny signifikantní rozdíly ani v tělesném složení, ani v kognitivních schopnostech. Nelze tedy říci, že by snížení příjmu cukru mělo vliv na tělesné složení či kognitivní funkce. Nakonec byla stanovena určitá doporučení, co se adekvátního př́ijmu cukru u experimentální skupiny týče.

KLÍČOVÁ SLOVA př́jem cukru; kognitivní funkce; tělesné složení; test LGT-3; učení; krátkodobá pamět

ABSTRACT Free sugars contribute to the overall energy density of diets and may promote a positive energy balance. According to WHO, the recommended sugar intake is 25 grams per day for an adult of normal BMI. According to Euromonitor International, the amount of sugar consumed per day in the Czech Republic is 71.6 grams. Excessive sugar intake can increase the risk of NCDs and various studies investigating the high sugar intake agree that sugar consumption could have an impact on the cognitive abilities of the person. The present study was aimed to determine the effects of high sugar intake on the body weight, body composition (using the BIA method - Bodystat 1500MDD), and learning abilities on a sample of university students $(\mathrm{N}=107)$ assigned into two groups. While the experimental group was instructed to stick to a sugar free diet, the control group had no specific diet prescribed. Selected variables were measured, by LGT-3 test and bioimpedance measurement, at the beginning of the experiment and after one month (33 participants completed the experiment). No significant differences in body composition or cognitive functions were found between the experimental and control groups after the experiment. Therefore we cannot conclude that reduction in sugar consumption has an impact on body composition or cognitive functions. Finally, a number of recommendations were formulated to encourage an adequate intake of sugar for the experimental sample.

KEY WORDS sugar intake; cognitive functions; body composition; LGT-3 test; learning; short-term memory

\section{INTRODUCTION}

When sucrose (commonly known as table sugar) is consumed the enzyme beta-fructosidase separates sucrose into its indivi- dual units of glucose and fructose. The body will use glucose as its main energy source and the excess energy from fructose, if not needed, will be used for fat synthesis, which is stimulated by the insulin released in response to glucose. Per WHO (2015), 
the recommended sugar intake is 25 grams per day for an adult of normal Body Mass Index (BMI). However, Euromonitor International (2014) in its report demonstrates that the amount of sugar consumed per day in the Czech Republic is 71.6 grams. Added sugars in processed food and soft drinks play a key part in the growing problems of and occurrence of noncommunicable diseases (NCDs). Its excessive consumption is related to obesity, diabetes and tooth decay. Various studies investigating the high sugar intake also agree that sugar consumption could have an impact on both the health and the cognitive abilities of the person (Wolraich et al., 1994; Bellisle, 2004; Benton, 2010; Kanoski - Davidson, 2011).

Excessive sugar intake can increase the risk of addiction. For this reason, sometimes sugar abstinence is forced to test patients' commitment and discipline in addiction treatment (Horák, 2013). A meta-analysis of studies of relation between sugar and behavior or cognitive function has shown little or no effect of sugar intake on cognitive performance in children, although the role of glucose in memory potentiation processes appears clear (White and Wolraich, 1995).

According to Hsu et al. (2015), excessive sugar consumption during adolescence produces neural and cognitive dysfunction and affects remembering critical information about our environment.

Research implemented among school-aged children by Gri$\mathrm{mm}$ et al. (2005) demonstrated that several factors may be associated with excessive sugar intake, especially in soft drinks, most notably taste preferences, consumption habits of parents and friends, availability in the home and school, and television viewing.

The available literature also supports the observation that people do not adequately compensate for the added energy they consume in soft drinks and non-nutritious foods and consequently increase their intake of sugar and total energy. These findings raise the possibility that soft drinks increase hunger, decrease satiety, or calibrate people to a high level of sweetness that generalizes to preferences in other foods (Vartanian et al. 2007).

The impact of sugar consumption on health continues to be a controversial topic. Stanhope (2016) mentioned that recent reports conclude that there are no adverse effects of consuming beverages containing up to $30 \%$ of energy requirement sucrose or high fructose corn syrup, and the conclusions from several meta-analyses suggest that fructose has no specific adverse effects relative to any other carbohydrate.

The present research was conducted to determine the effects of high sugar intake on body composition, weight and learning abilities of university students.

\section{AIMS OF THE STUDY}

The aim of this project was to determine whether abstinence from sugar (in the experimental group) influences body composition and cognitive and learning abilities (in comparison with the control group) of university students.

\section{METHODS AND PROCEDURES}

The research was separated into three stages. The first stage (Stage 1) was to get to know the eating habits, body composition and learning abilities of the participants. In the second stage (Stage 2), the participants were divided into two groups. One group got a special diet, while the other group did not. Finally, in the third stage (Stage 3) the learning abilities and body composition of the subjects were measured again.

In the Stage 1, the eating habits of the participants were evaluated. The participants were given a personal information questionnaire. This questionnaire, which consisted of 37 questions, was divided into 4 blocks: overall overview, health, food habits and sugar consumption. With the filled in questionnaire it was possible to determine each subject's daily sugar intake. The daily sugar intake was determined with use of the website http://www.kaloricketabulky.cz/, where the sugar content was found for most of the products the participants stated in the questionnaire they consumed.

After the Stage 1 was finished, the participants were sorted into two groups. To the group with the special diet (Group 1 ), those subjects were assigned who had more than $25 \%$ (for women) and $18 \%$ (for men) of body fat or if they consumed the amount of sugar equivalent to more than one gram of sugar per kilogram of body weight per day. The participants in Group 1 needed to stick to their diet for four weeks. The other participants (Group 2 or control group) did not need to stick to any special diet.

The Group 1 was required to stick to a special diet because according to our hypothesis, a high consumption of free sugars might have some influence on their short- term memory and cognitive abilities. Because of this, different results were expected to be found in the psychological test carried out in the Stage 1 and Stage 3 of this research.

The special diet consisted of recommendations about how to minimize the daily free sugar intake. For example, the participants were expected not to consume any sweets and sweetened beverages.

The body composition and the learning abilities of the participants were measured during the Stage 1 and Stage 3. The psychological tests were carried out only in the mornings and only after the participants have rested for at least five minutes in seated position.

\section{Physiological measure}

To get a better picture of the participants' health, the amount of fat in their bodies was measured. The participants' body height and weight were first measured and recorded using standard anthropometric procedure and apparatus (GPM anthropometer to measure body height, digital scale to measure body weight). The BMI of the subjects was calculated based on measured values. Then their body composition was analyzed using Bodystat (model 1500MDD) equipment. The analysis (together with the anthropometric measurement) was carried out always in the mornings, as recommended by the standard 
anthropometric procedure. The subjects were advised not to consume alcohol for 24 hours and neither to exercise for 12 hours prior to the analysis. Moreover, they were told not to eat or drink 5 hours prior to the testing, and to have an empty bladder.

\section{Cognitive measure}

The learning abilities of the subjects were investigated by the Czech adaptation of slovak version of LGT-3 learning and memory test (Maršálková et al., 1992). The LGT-3 is a learning and memory test, which has two parallel forms (Form A and form B). The test consists of six tasks in fixed order: (1) city plan, (2) vocabulary, (3) objects, (4) telephone numbers, (5) building construction and (6) corporate brands. Three of the tasks investigate verbal/numerical memory (tasks 2, 4, 5) and three visual memory (tasks 1, 3, 6). After reading the instructions for each task, respondents had one minute ( 2 minutes in task 4) to memorize the content of the task. After memorizing all six subtests the subjects were supposed to recall the content of the tasks and plot it in the answer sheet. The number of correct responses in each task was counted and the final score of the test was computed for each participant. The maximum score of both forms is 135 .

\section{Research sample}

This study was carried out between February to April 2016. The participation was voluntary and anonymity granted as each participant was assigned a unique code. During this period 107 respondents participated in the research, from which only $33(35 \%)$ completed all the stages of the research. Of all the subjects who completed the study 27 (82\%) were women and $6(18 \%)$ were men. The subjects were between 18 to 26 years old. At the end, 16 students followed the sugar free diet and 17 students were in the control group with no diet.

\section{Statistical analyses}

The statistical analysis was performed in the IBM SPSS Statistics 23 software pack. Independent samples t-tests were used to compare body fat percentages and cognitive functions in the experimental and control groups. Pearson correlation was used to find out if a relationship exists between body composition and cognitive skills.

\section{RESULTS}

\section{Body fat percentage}

During the First stage, 82 subjects ( $76 \%$ of the recruited sample) were measured. This group counted with the participation of 68 women and 32 men. The results of the first BMI measurement indicated that the group was divided into three categories: $76 \%$ had a normal weight, $13 \%$ were overweight and $11 \%$ were obese. Later, along the Third stage, 33 subjects
(31\%) were measured once more. This group was composed of 27 women and 6 men. The results of this second measurement indicated that the group was divided also into three categories: $82 \%$ had normal weight, $9 \%$ were overweight and $9 \%$ were considered obese.

The working hypothesis stated that cutting down on sugar intake would have an effect on body composition (in the sense of body fat percentage decrease). Two approaches were taken to test this hypothesis. The first approach consisted of testing the group differences in body composition statistically. The second, individual approach was based on "factual" significance testing.

\section{Statistical testing}

An independent samples t-test was conducted to compare the body fat percentage in the experimental and control groups (Table 1). There was not a significant difference in the scores for the experimental and control groups; $p=0.345$. These results suggest that body fat percentage did not change in any of the groups. Specifically, our results suggest that body fat percentage of the experimental and control group members did not change.

\section{Individual testing}

Based on the observations of Kutác (2012) who used Typical error of measurement to establish the "factual" significance in body fat percentage changes (Typical error of measurement is used to determine the typical error based on many repeated measurements and thus to establish the threshold when the determined change can be considered a result of external intervention and not an error of measurement) we proceeded to assess the biological importance of the difference between the experimental and control group. Following Kutáčs findings we established the value of change above $0.5 \%$ BF to be biologically significant.

\begin{tabular}{|l|c|c|}
\hline BF percentage change & Mean & SD \\
\hline Experimental group & $-1.59 \%$ & 0.52 \\
\hline Control group & $-0.85 \%$ & 0.56 \\
\hline
\end{tabular}

Table 1: Change in body fat percentage in the experimental and control groups

Overall the members of the experimental group lost almost $1.6 \%$ of fat during the intervention while the control group members lost $0.85 \%$ of body fat. This result indicates that in both groups overall the change has factual significance. However, to understand the nature of these changes we need to look at the data more closely.

In the experimental group, only two participants gained body fat compared to four participants in the control group above the level of measurement error. Nine participants from the experimental group lost body fat and in the control group, also nine participants lost body fat above the level of measurement 
error. The absolute values of biologically significant (above the level of measurement error) changes are also very similar in both groups, therefore it seems that the intervention had no effect on body fat percentage.

\section{LGT-3}

We hypothesised that lower sugar intake would improve the learning abilities of participants in a diet condition.

\section{Statistical testing}

We conducted an independent samples t-test comparing a diet and non-diet conditions sample. Therefore, we compared the total scores of the second administration of the test of respondents in a diet $(\mathrm{M}=80.5, \mathrm{SD}=14.4)$ and no-diet $(\mathrm{M}=73.4, \mathrm{SD}=23.4)$ condition. Although the respondents in a diet condition performed better in the LGT-3 test, the differences between both groups were not significant, $\mathrm{t}(31)=1.05, \mathrm{p}=0.30)$.

For a purpose of comparison of the relative difficulty of both test forms we performed an additional analysis. We compared the results of Form B (before the experimental manipulation) and Form A (after the manipulation) overall test scores in whole research sample. The results of the comparison of both forms suggest that the performance in the first administration of the test $(\mathrm{M}=93.8, \mathrm{SD}=17.3)$ compared to the second administration $(\mathrm{M}=77.0, \mathrm{SD}=19.3)$ is significantly better, $\mathrm{t}(32)=6.0, \mathrm{p}<0.001$. Additionally, we tested potential sex differences in cognitive performance in both administrations of the test with no significant results in any of the LGT-3 test and subtest scores. The implications of the cognitive performance results will be discussed in the next section.

\section{The relationship of cognitive and physiological varia- bles with the body fat percentage}

We correlated the LGT-3 test results with the body fat percentage and BMI. No statistically significant relationships were found.

\section{DISCUSSION}

The aim of this research was to determine, whether a high sugar intake influences the learning and memory abilities of university students.

The research was separated into three stages. The first stage (Stage 1) was to get to know the eating habits and learning abilities of the participants. In the second stage (Stage 2), the participants were divided into two groups. One group was asked to stick to a special diet, while the other group was not. Finally, in the third stage (Stage 3) the learning abilities of the subjects were measured again.
One hundred seven subjects were participating in the first stage of the study. Of these 74, because of time constraints or general disinterest, elected not to participate in the second and the third stage of the study.

The obtained data from the 33 participants who endured until the end of the experimental period, does not show a significant correlation between high sugar intake and body fat accumulation and/or an effect on memory and learning abilities. The subjects of this research lost (or gained) fat similarly during the monitoring period (one month), despite the experiment group was instructed to limit their intake of free sugars.

The results are consistent with the existing and documented controversy - abundant epidemiological data exist that provide a strong support for the indirect role of sugar consumption in body fat gain, yet some sponsored studies claim that sugar intake (mainly from high sucrose beverages) has no adverse effects. But, conflict of interest may fuel this controversy, since these reports were industry - funded or were conducted by investigators who have received consulting fees from industries with a strong financial interest in maintaining high levels of sugar consumption (Stanhope 2016). However, in our research we were confronted with two potentially detrimental circumstances: the study period was relatively short (for reasons out of our control); it would have been preferable to count on more than (potentially insufficient) one month of monitoring for both groups (although interventions as short as 11 days, and the reduction of 35\% of the energy intake, proved to influence body composition (McCrory 1999). Similarly, we could not prevent the drastic amount of participant loss during the monitoring period.

In relation with the LGT-3 test, the participants fared worse in the second measurement. This result could be related with the fact that the test was harder or the participants had a lower motivation.

\section{LIMITS OF THE STUDY}

Most of the participants were characterized as having normal weight (BMI categorization) $-82 \%$ of the subjects were considered healthy. Also, the failure of the participants to comply with the conditions established for the measurement of the body fat percentage (Bioelectrical impedance analysis), the diet (some were advised to follow it and they did not and vice versa, perhaps to have a better - or worse- result in the second body composition testing) and the specifications about their food intake before taking the LGT-3 test were other possible limitations; although the participants were informed before via a brochure, the actual adherence the instructions could not be guaranteed. Also, as mentioned above, an important loss of participants was observed and the designed length of the experiment did not correspond with the actual length. 


\section{CONCLUSION}

In our study, we aimed to find if there is a relation between excessive sugar intake and body composition and cognitive performance. No significant differences in body composition or cognitive functions were found between the experimental and control groups after the experiment. Therefore, we cannot conclude that reduction in sugar consumption has an impact on body composition or cognitive functions.

Finally, several recommendations were formulated to encourage an adequate intake of sugar for the experimental sample.

\section{REFERENCES}

Bellisle, F. (2004): Effects of Diet on Behaviour and Cognition in Children. British Journal of Nutrition, 92(2), 227-232.

Benton, D. (2010): The Plausibility of Sugar Addiction and Its Role in Obesity and Eating Disorders. Clinical Nutrition, 29(3), 288-303.

Euromonitor International (2014): The Sugar Backlash and Its Effects on Global Consumer Markets. London: Euromonitor International Ltd.

Grimm, H. C. - Harnack, L. - Story, M. (2004): Factors associated with soft drink consumption in school-aged children. Journal of American Dietetic Association, 104(8), 1244-1249.

Horák, M. (2013): The House of Song. The Rehabilitation of Drug Addicts by the Traditional Indigenous Medicine of the Peruvian Amazon. Brno: Mendel University in Brno.

Hsu, T. M. - Konanur, V. R. - Taing, L. - Usui, R. - Kayser, B. D. - Goran, M. I. - Kanoski, S. E. (2015): Effects of Sucrose and High Fructose Corn Syrup Consumption on Spatial Memory Function and Hippocampal Neuroinflammation in Adolescent Rats. Hippocampus, 25(2), 227-239.

Kanoski, S. E. - Davidson, T. L. (2011): Western Diet Consumption and Cognitive Impairment: Links to Hippocampal Dysfunction and Obesity. Physiology \& Behavior, 103(1), 59-68.

Kutáč, P. (2012): Application of Typical Error of Measurement for Accuracy of Measurement of Body Composition in Athletes Using the BIA Method. Medicina Sportiva, 16(4), 150-154.

Maršálková, L. - Hrabovská, A. - Meszárošová, B. (1992): Pamätový test LGT - 3. Bratislava: Psychodiagnostika.

McCrory, M. - Nommsen-River, L. - Molé, P. - Lonnerdall, B. - Dewey, K. (1999): Randomized Trial of the Short-term Effects of Dieting Compared with Dieting Plus Aerobic Exercise on Lactation Performance. The American Journal of Clinical nutrition, 69(5), 959-967.

Stanhope, K. (2016): Sugar Consumption, Metabolic Disease and Obesity: The State of the Controversy. Clinical laboratory science, 53(1), 52-67.

Tate, D. F. - Turner-McGrievy, G. - Lyons, E. - Stevens, J. - Erickson, K. - Polzien, K. -Diamond, M. - Wang, X. - Popkin, B. (2012): Replacing Caloric Beverages with Water or Diet Beverages for Weight Loss in Adults: Main Results of the Choose Healthy Options Consciously Ev- eryday (CHOICE) Randomized Clinical Trial. The American Journal of Clinical Nutrition, 95(3), 555-63.

Vartanian, L. R. - Schwartz, M. B. - Brownell, K. D. (2007): Effects of Soft Drink Consumption on Nutrition and Health: A Systematic Review and Meta-Analysis. American Journal of Public Health, 97(4), 667-675.

WHO (2015): Sugar Intake for Adults and Children. Genewa: WHO Document Production Services.

White, J. M. - Wolraich, M. (1995): Effect of sugar on behavior and mental performance. American Journal of Clinical Nutrition, 65(1), 242-247.

Wolraich, M. L. - Lindgren, S. D. - Stumbo, P. J. - Stegink, L. D. - Appelbaum, M. I. - Kiritsy, M. C. (1994): Effects of Diets High in Sucrose or Aspartame on the Behaviour and Cognitive Performance of Children. The New England Journal of Medicine, 5(330), 301-306. from the Technical University of Madrid - Spain. She is currently doing her PhD. at Mendel University in Brno. The subject of her professional interest is related with the areas of nutrition, food composition, food chemistry and food processing. Her thesis is focuses on the use of nontraditional raw materials for brewing beers and baking breads.

Contact: Engineer Joany Lizet Hernández Kong, Mendel University in Brno, třída Generála Píky 2005/7, 61300 Brno - Černá Pole. Email: joany.hernandez.kong@gmail.com

Jiří Čeněk (25. 5. 1984, Plzeň), Faculty of Arts, Masaryk University graduate, is curently finishing his $\mathrm{PhD}$ of Social Psychology and teaching psychology-related courses at Faculty of Regional Development and International Studies, Mendel University in Brno. His research interests are related to the cultural adaptation process and cross-cultural differences in perception and cognition.

Kontakt: Ing. Mgr. Jiří Čeněk, Faculty of Regional Development and Internetional Studies, Mendel University in Brno, Zemědělská 1, 61300, Brno. E-mail: jiri.cenek@mendelu.cz

Martin Čuta (18. 1. 1979, Brno), works as an assistant professor at the Department of Anthropology, Faculty of Science, Masaryk University (Brno). He focuses his research on physical anthropology growth and development, functional anthropology, sports anthropology and anthropometry. His teaching activities include courses of anatomy for anthropologists, methodological and introductory courses in anthropology.

Contact: Mgr. Martin Čuta, PhD. Dept. of Anthropology, Faculty of Science, Masaryk University, Vinařská 5, 603 00, Brno. E-mail:cuta@ sci.muni.cz 
